УДК 330.322(479.25)

(C) 2013

Петросян С. А., кандидат экономических наук, Манучарян М. Г., аспирант*

Государственный аграрный университет Армении

\title{
СИСТЕМА СТРАХОВАНИЯ ОТ РИСКОВ ИНВЕСТИЦИОННОЙ ДЕЯТЕЛЬНОСТИ В АРМЕНИИ - ВАЖНАЯ СОСТАВЛЯЮЩАЯ ИНВЕСТИЦИОННОГО КЛИМАТА
}

\section{Рецензент - доктор экономических наук, профессор Г. М. Мамиконян}

\begin{abstract}
Обосновывается важность страхования инвестииионных рисков для привлечения иностранных инвестиций в Армении. Для уменьшения степени политического риска иностранных инвесторов важно и их правильное информационное обеспечение. Как показывает практика, независимо от реального состояния инвестиционной обстановки данной страны, иностранные инвесторы склонны рассматривать как страну с наибольшей степенью риска ту, о которой они имеют минимум информации. Для будущего Армении этот факт крайне важен. А поскольку Республика Армения представляет собой страну «молодую» (начиная с момента получения независимости в начале 90-х г2.), с ограниченным пространством, малой численностью населения, располагаюшуюся в нестабильном регионе со сложеными политическими отношениями с двумя странами-соседями (Азербайджаном и Туричией), то Армения не всегда надлежашим образом предстает перед иностранньм инвестором в плане политическом, экономическом, социально-культурном.
\end{abstract}

Ключевые слова: инвестиционный риск, страхование, конфискации, вкладчик, инвестор, корпорация.

Постановка проблемы. Особое значение для иностранных инвесторов имеют инвестиционные риски, связанные с опасностью утраты собственности, с сохранением права собственности. В качестве первого примера, связанного с указанными рисками, можно рассмотреть пример с экономической деятельностью, где при возможном возникновении отрицательного влияния причиной оказываются недостатки организации производственного процесса. К числу убытков, возникающих по причине указанных рисков, относятся: недополученная прибыль, убытки, нарушение установленного срока возвращаемого кредита дебитором и т.д. Следующим видом являются технические риски, которые возникают при пожаре, взрыве, наводнении, авариях и других возможных подобных катаклизмах XXI века либо при технических неполадках. Для получения возможных гарантий при вышеуказанных двух рисках иностранные инвесторы пользуются услугами страховых компаний.

Анализ основных исследований и публикации по данной проблеме. Для Республики Армения, начиная с 90-х годов XX столетия, актуально существование так называемых политических рисков и их исследование, так как такие риски являются специфическими для каждой отдельно взятой страны. К политическим рискам можно отнести: возможности конфискации имущества иностранного вкладчика по возникшим политическим причинам (захват власти экстремистами или государственный переворот), возможность уничтожения или потери имущества иностранного вкладчика из-за политических волнений или войны, изменения по отношению к деятельности иностранных инвесторов из-за внутриполитических изменений и под.

Как свидетельствует анализ специальной литературы, разными авторами наличие политических рисков для иностранных инвесторов классифицируется по-разному [1-4].

В ряде случаев составляющую часть политических рисков рассматривают как явление политической нестабильности, которая проявляется при политических переворотах, противогосударственных забастовках, гражданской войне и других тождественных проявлениях. Однако они случаются очень редко и не относятся к важнейшим факторам, беспокоящим иностранных инвесторов. Отмеченное, в основном, относится к иностранному инвестору, который уже развернул свою инвестиционную деятельность в данной стране.

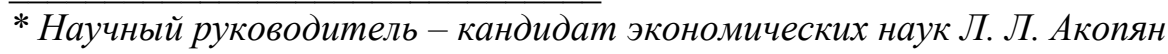


Для потенциальных иностранных инвесторов политическая нестабильность выступает в виде, по меньшей мере, непривлекательной действительности и, более того, - в виде ограничивающей действительности. Так, проведённый в Восточной Европе опрос руководителей фирм, желающих развернуть свою инвестиционную деятельность, показывает, что иностранные инвесторы подразумевают в качестве главных три основных обстоятельства, отдавая при этом первенство политической стабильности (78\% от числа опрошенных участников). Как следующий важнейший фактор отмечается фактор объёма внутреннего рынка (52\%), наличие опытной рабочей силы (29\%), географическое расположение $(24 \%)$, уровень развития инфраструктуры (7 \%) и только $2 \%$ обращают внимание па наличие налоговых льгот.

Возникновение политической нестабильности и для действующих, и для потенциальных вкладчиков является фактором беспокойства, особенно когда вследствие таких событий возникают внутренние и внешние напряжения, для преодоления которых правительство меняет «правила игры» для иностранных инвесторов (политические риски, относящиеся к правительству). К перечисленным рискам можно отнести риски, возникшие при изменениях в системе налогообложения иностранных предприятий, в вывозе полученной прибыли, обмене валюты, возможности изменения в упорядочении норм владения собственностью, о чем свидетельствуют итоги опросов, проведенных среди действующих на территории Армении инвесторов и экспертов.

Специфика Армении состоит в том, что, несмотря на определённые сложности во внутри политической жизни страны, политические риски в значительной степени связаны с региональной политической нестабильностью. В Армении при существующих условиях нестабильной внешней обстановки политические риски связаны с устроенной Азербайджаном и Турцией экономической блокадой, а также с обострившейся политической ситуацией в Грузии и на Южном Кавказе в целом. Перспективы политической обстановки в Азербайджане и Грузии в настоящее время выглядят достаточно неопределённо, что, естественно, негативным образом отражается и на Армении. Что же касается взаимоотношений с Турцией, то руководство Армении стремится к их улучшению, ожидая при этом ответных шагов с противоположной стороны.

Не причисляя к важнейшим факторам, имеющим воздействие на иностранные инвестиции, факт региональной нестабильности, все-таки отметим, что он имеет негативное воздействие прежде всего на не имеющих опыта работы инвесторов и тех, кто готовится вывозить произведённый продукт на внешний рынок, не ограничиваясь армянским, - достаточно компактным рынком. Однако в целом сохранение региональной стабильности - это та область, которая требует немедленного решения.

С точки зрения оценки внешнеполитических рисков надо положительно оценить качество двухсторонних отношений Армении и основных её стран-партнеров (Россия, США, страны Европейского Союза, Иран, арабские страны. При этом огромное, во многом определяющее значение имеет и должно иметь в будущем политическое взаимодействие Армении и России).

Нет необходимости доказывать, что для иностранных инвесторов уровень этих двусторонних связей, их стабильность или, в лучшем случае, развитие имеют принципиальное значение. Ухудшение или ослабление этих связей может стать ещё одним поводом для колебаний иностранных инвесторов. Так, ухудшение отношений между государствами может привести к установлению эмбарго или двухстороннему экономическому бойкоту, к ограничению движения капитала или его приостановке.

К политическим рискам в определённой степени примыкают социальные риски (которые в некоторых случаях выступают как социальнокультурные риски). В основе такого рода рисков лежит особое (нередко негативное) восприятие населением принимающей страны части иностранных инвесторов из-за имевших место ранее или имеющих место в настоящее время исторических, политических противоречий, острых конфликтов, войн, различий в обычаях, культуре и т. п.

Хотя в случае с Арменией общество в целом достаточно либерально относится почти ко всем иностранным инвесторам, и, как свидетельствуют факты, иностранные инвесторы (независимо от того, какие страны представляют) в основном позитивно воспринимаются населением республики и в целом довольны отношением к себе. Сказанное не относится лишь к ряду естественных монополий (связь, энергораспределительные сети) и традиционным отраслям (производство коньяка), торговой деятельности, присутствие в которых иностранных компаний удостаивается отрицательной оценки разных слоёв населения Республики Армения.

Для понижения возможных отрицательных 
воздействий политических рисков в Армении необходимо выработать ряд правил по применению страховых мер на частном и правительственном уровне, на внутреннем и межгосударственном уровне. В основе этого процесса лежит, безусловно, создание юридической базы, защищающей права инвесторов.

Как уже были сформулированы предложения по нормативно-правовой базе Армении, и, прежде всего в связи с законом Республики Армения «Об иностранных инвестициях», режим, установленный внутренним законодательством по защите иностранных инвесторов от политических рисков, последними не считается абсолютной гарантией. Государство, по сути, само «дарит» гарантии по отношению к хозяйственной деятельности собственников, и именно само государство (а не третья независимая сторона) контролирует качество предоставляемых гарантий. Более продуктивным методом на межправительственном двухстороннем уровне считается заключение соглашений по защите и стимулированию вкладов.

Еще одним продуктивным методом сведения к минимуму политических рисков является существование независимых судебных систем.

Цель исследования - обосновать важность страхования инвестиционных рисков для привлечения иностранных инвестиций в Армении.

Результаты исследований. Для уменьшения степени политического риска иностранных инвесторов важно и их правильное информационное обеспечение. Как показывает практика, независимо от реального состояния инвестиционной обстановки данной страны, иностранные инвесторы склонны рассматривать как страну с наибольшей степенью риска ту, о которой они имеют минимум информации. Для будущего Армении этот факт крайне важен. А поскольку Республика Армения представляет собой страну «молодую» (начиная с момента получения независимости в начале 90-х гг.), с ограниченным пространством, малой численностью населения, располагающуюся в нестабильном регионе со сложеными политическими отношениями с двумя странами-соседями (Азербайджаном и Турцией), то Армения не всегда надлежащим образом предстает перед иностранным инвестором в плане политическом, экономическом, социально-культурном.

Следующий, более продуктивный метод защиты иностранных инвесторов от политических рисков - это метод использования страховых компаний. Однако обычные страховые договора, заключённые частными страховыми фирмами, рассматривают политические риски под «форсмажорными» обстоятельствами, и риски в большинстве случаев не компенсируются. Только в последние годы стало наблюдаться повышение активности со стороны частных страховых фирм в деле зашиты от политических рисков. На территории бывшего Советского Союза от политических рисков малого объёма страхованием занимаются английская страховая компания «Lloyd's», немецкая «Germes» и американская «ALG». В Армении французская страховая компания «Coface», которая практикуется в страховании внешнеэкономической деятельности, застраховала компанию «Alcatel» в сфере коммуникаций на сумму $\$ 40$ млн.

Плодотворным методом страхования инвестиционной деятельности, наряду с частными страховыми компаниями, является создание крупных фирм под покровительством государства или его непосредственным участием.

Поддержкой инвестиционных программ с участием иностранных компаний может стать участие государства или международной финансовой организации в данном проекте. Такое участие, не включая в себя непосредственные элементы, присущие страхованию, как показывает международная практика, в то же время является убедительным гарантом для иностранного инвестора. Для иностранного инвестора факт участия государства в инвестиционном проекте является гарантией того, что само государство заинтересовано в благополучной реализации проекта, а участие международной организации в какомлибо проекте позволяет предполагать, что данные организации в случаи необходимости используют все имеющиеся на вооружении рычаги и методы для воздействия на правительство данной страны, подразумевая при этом снятие всех преград.

В США и в ряде других стран созданы специализированные учреждения, так называемые «Государственные агентства по предоставлению гарантий», основной целью которых является координирование работ государства по инвестированию, в которых в той или иной степени привлечены и государственные средства. Государственное участие в инвестиционных программах может проявляться следующим образом:

- в качестве собственника, то есть часть акций компании находится в собственности у государства;

- кредитование по льготным условиям;

- субсидирование инвестиционных программ. 
Как представляется, в Армении время создания такого рода агентства уже пришло, однако для этого сначала надо обеспечить соответствующую нормативно-правовую базу.

Ряд государств, стремясь защитить национальные компании, делающие вклады за рубежом, сами осуществляют страхование экспортируемого капитала. Примером может стать действующая в США Корпорация частных иностранных инвестиций (Overseas Private Investment Corporation - OPIC), которая оказывает помощь американским предпринимателям при осуществлении инвестиций за рубежом. Помощь проявляется при страховании прав собственности от политических воздействий, предоставлении консультационных услуг, при финансировании долгосрочных и краткосрочных инвестиционных программ. В сферу деятельности ОРІС включена и Республика Армения, где уже застрахованы ряд программ с участием американской стороны.

Для осуществления страхования от неторговых (политических) рисков еще в 1985 г. было создано Многостороннее агентство по защите инвестиции (Multilateral Investment Guarantee Agency - MIGA), членами которого в настоящее время являются свыше 160 государств мира, в том числе и Армения. Основная деятельность MIGA связана с предложениями долгосрочных

\section{БИБЛИОГРАФИЯ}

1. Закон Республики Армения от 4 июля 1994 г. «Об иностранных инвестициях».

2. Зубченко A. A. Иностранные инвестиции. - М. : Эксмо, 2006. услуг по страхованию от политических рисков, предоставлением консультационных и маркетинговых услуг. За годы деятельности M1GA число стран-членов этого Агентства резко увеличилось, так же, как и объём сделок по страхованию.

В 2000 г. в MIGA большое число гарантий из стран-участниц приходилось на США и страны Карибского бассейна, которые вовлекли $45 \%$ от общего объёма страховок, 24-25 \% составляют страны Центральной и Восточной Европы и республики бывшего Советского Союза. Крупнейшими по страховому сотрудничеству с MIGA из стран-соседей и партнеров Республики Армения являлась Россия (страхование на \$340 млн) и Турция (\$ 230 млн). В Азербайджане (\$ 19 млн) и Грузии (\$2 млн) MIGA также осуществляла страховые программы. В Армении со стороны MIGA не было осуществлено ни одной страховой программы, и только в последнее время начались работы в этом направлении, которые, безусловно, необходимо активизировать.

Выводы. Таким образом, система страхования от рисков инвестиционной деятельности является важной составляющей частью инвестиционного климата страны, которая создаст благоприятные условия для привлечения иностранных инвестиций в Армению.

3. Ковалев Н. В. Инвестиции. - М. : Эксмо, 2004. 4. Шакарян T. Н. Стратегия привлечения иностранных инвестций в Республику Армения. - М. : Эксмо, 2008. 